\title{
Knowledge and Attitude of Taif University Students on Stem Cell Banking
}

\author{
Majid Alhomrani ${ }^{1,2, *}$, Abdulhakeem S. Alamri ${ }^{1,2}$, Walaa F. Alsanie ${ }^{1,2}$, Ashwag E. Alrobiey ${ }^{1}$, \\ Raghad M. Asiri', Shahad M. Alaseri', Basmah K. Alghamdi', Sara A. Almalki', Osama Abdulaziz ${ }^{1}$, \\ Syed Mohammed Basheeruddin Asdaq ${ }^{3}$, Nagaraja Sreeharsha ${ }^{4,5}$
}

${ }^{1}$ Department of Clinical Laboratory Sciences, College of Applied Medical Sciences, Taif University, Taif, SAUDI ARABIA, ${ }^{2}$ Centre of Biomedical Sciences Research (CBSR), Deanship of Scientific Research, Taif University, Taif, SAUDI ARABIA. ${ }^{3}$ Department of Pharmacy Practice, College of Pharmacy, AIMaarefa University, Dariyah, Riyadh, SAUDI ARABIA.

${ }^{4}$ Department of Pharmaceutical Sciences, College of Clinical Pharmacy, King Faisal University, Al-Hofuf, Al-Ahsa, SAUDI ARABIA.

${ }^{5}$ Department of Pharmaceutics, Vidya Siri College of Pharmacy, Off Sarjapura Road, Bangalore, Karnataka, INDIA.

\begin{abstract}
Background and Objectives: The awareness of university students is pivotal to the adaptation of new therapeutic technologies in combating illness and disorders. Stem cells are unique and effective in treating several pathological conditions. This study was an effort to determine the knowledge and attitude of Taif University students toward the banking of stem cells through the donation of umbilical cord blood (UCB). Materials and Methods: The study used a self-administered questionnaire that consisted of items on demographics, knowledge characteristics, and attitude towards banking of UCB as a source of stem cells for the purpose of achieving advanced therapeutic outcomes. The questionnaire was administered to only female students at Taif University during the academic year 2020-21. Both descriptive and inferential analysis were done using SPSSIBM 25 to analyze the data. Results: A total of 604 female students of Taif University responded to our questionnaire. Although most of the participants (70\%) lacked sufficient knowledge (less than or equal to 2 out of 4), their attitudes were motivating, with more than $60 \%$ rated better than adequate (more than or equal to 3 out of 4 ). Many study participants have shown an interest in donating umbilical cord stem cells to treat other patients and for research purposes. Conclusion: Students with good knowledge of umbilical cord blood donation and those who are more educated showed a greater level of willingness to participate in banking and donation of stem cells. Therefore, raising awareness about stem cell banking and its importance among young undergraduates, especially female students, is imperative.
\end{abstract}

Key words: Knowledge, Attitude, Taif University, Awareness campaigns, Umbilical Cord blood.

\section{INTRODUCTION}

Umbilical Cord Blood (UCB) was previously assumed to be medical waste, but that is no longer the case. Hematopoietic stem cells (HSCs) from UCB are now widely recognized as a valuable alternative to bone marrow and peripheral blood HSCs. ${ }^{1} \mathrm{UCB}$ has gained appeal as a feasible therapy option for hematologic and oncologic disorders, with results comparable to bone marrow and peripheral blood transplants. ${ }^{2}$ Hematopoietic stem cell transplantation (HSCT) is now utilized to treat a wide range of conditions, including acute, ${ }^{3}$ and chronic leukemia, ${ }^{4}$ myelodysplastic syndromes, ${ }^{5}$ thalassemia, ${ }^{6}$ aplastic anemia, Fanconi anemia, ${ }^{7}$ bone marrow failures, immunological deficiencies, ${ }^{8}$ and metabolic illnesses. ${ }^{7}$ UCB also contains mesenchymal stem cells (MSCs), endothelial progenitor cells, and immunological cells, all of which have the potential to reveal innovative therapeutic approaches for a variety of undiagnosed disorders.
Submission Date: 28-05-2021; Revision Date: 29-07-2021; Accepted Date: 10-09-2021

DOI: 10.5530/ijper.56.1.35 Correspondence: Dr. Majid Alhomrani, Department of Clinical Laboratory Sciences, College of Applied Medical Sciences, Taif University, Taif, SAUDI ARABIA. E-mail:m.alhomrani@ tu.edu.sa

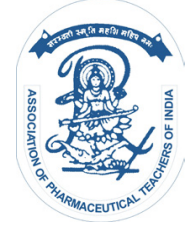

www.ijper.org 
On a case-by-case basis, the preservation of UCB is carried out. People, their families, and the public should be made aware of this chance to collect and conserve UBC for the wide range of treatment choices it offers. Because the quality of knowledge that is transmitted will have a considerable impact on parents' decisions about whether to incinerate or bank their child's UCB, it's vital to assess our community's level of comprehension about $\mathrm{CB}$ banking, as well as the reliability of the information they get. ${ }^{9}$

Several hundred thousand UCB units are currently held in public cord blood banks (CBBs) around the world, ready to be used by any patient in need of stem cell transplantation. Saudi Arabia currently has two state $\mathrm{CBBs}$ and no private banks due to legal restrictions. Both public banks provide associated banking services to families who have a history of hematological disorders. Additionally, several private companies provide collection services to families who want to store their UCB in private banks and move it to international storage facilities.

Number of studies have been carried out in various regions to explore more about people's knowledge, understanding, preferences, and attitudes concerning $\mathrm{CB}$ banking. The outcome of these studies is inconsistent in terms of the level of knowledge reported across the population. Sadly, most data demonstrated a lack of understanding among the public, pregnant mothers, and even medical experts or health care providers. ${ }^{10,11}$ The purpose of this study was to determine the extent of public awareness of $\mathrm{CB}$ banking in Saudi Arabia.

Considering CB banking has such a promising future, it is vital for health care professionals and medical and allied health sciences students to have a fundamental awareness of UCB as well as a positive attitude toward their usage in medicine. Hence, by a cross sectional design, this study was done to explore the knowledge level and pattern of attitude of Taif University female students on Umbilical cord blood banking and its donation for future use.

\section{MATERIALS AND METHODS}

\section{Study design and settings}

A cross-sectional study was conducted among Taif University's female students. Taif is a Saudi city on the eastern slopes of the Sarawat Mountains in the Makkah region of western Saudi Arabia. This study drew 604 students from the university's medical and allied health sciences programs, accounting for more than half of the university's female students.

\section{Sample size estimation}

The sample size was calculated using Cochrane's sample size equation $\left(n=\mathrm{z}^{2} \mathrm{pq} / \mathrm{e}^{2}\right)$, where ' $\mathrm{n}$ ' represents the smallest sample size, ' $z$ ' represents the targeted confidence interval (95 percent), $\mathrm{p}$ represents the proportion, $\mathrm{q}=1 \mathrm{p}$, and e represents the required level of precision (5 percent). We used $50 \%$ as the population proportion to compute the sample size for this study (p). Using the above formula and values with a finite population of 1400, the projected sample size was 325 .

\section{Sampling method}

A multilevel probability proportional to size (PPS) selection strategy was used to choose the study participants. To commence, the required percentage of participants from each college was calculated based on the total number of female students enrolled at that college. In the next steps, the required fractions of participants from each year were selected based on PPS. Using each student's university identity number, a systematic random sample procedure was used to select each year.

\section{Ethical considerations}

Taif University's Ethics Committee accepted this project with application number (43-006). Prior to participating in this study, all participants were asked if they agreed or disagreed to participate.

\section{Data collection procedure}

After all the necessary approvals had been fulfilled, the data collection procedure commenced. Their class leader informed them of the selected pupils' availability for data collecting. For the academic year 2020-21, the study comprises all female students enrolling at Taif University colleges. Between December 2020 and February 2021, the study team contacted the selected students, supplied an electronic link to the questionnaire, and got on-the-spot feedback. Respondents were free to answer the individual items without being compelled or interrogated by the researcher.

\section{Data collection instrument}

The researchers constructed the survey items for this study based on the most important data that needed to be acquired to measure knowledge and attitude trends. Both logical and content validity in relation to the study objectives were verified with the help of competent researchers and specialists in the field. The questionnaire was then translated into Arabic to make the substance of the survey more understandable to the surveyors. The Arabic translation was compared to the English version for logical and construction correctness 
with the help of bilingual (Arabic-English) speakers. A small sample of the population was also subjected to a pilot study to examine whether there were any missing points or if the respondents had any difficulties interpreting the questionnaire items. There were three sections to the questionnaire form. Section 1 contains demographic information such as age, educational level, marital status, nationality, motherhood, number of children, and source of cord blood stem cell banking information. Section 2 contained four items to test the participants' knowledge, whereas section 3 contained four things to test the surveyors' attitude pattern. For this survey, the traditional scoring method was used (1 point for the right and 0 points for the wrong answers in the knowledge section; similarly, 1 point for the positive and 0 points for the negative choices in the attitude section). The survey's score ranges were 0-4 for knowledge, 0-4 for attitude, and 0-8 for the overall score.

\section{Data analysis}

The data was analyzed using SPSS 25.0 software. The t-test was employed to compare mean estimations of variables. The Chi-square test was used to compare ratios and demographic factors. Pearson and Spearman's correlations were used to compare the correlations between two variables. $p<0.05$ was used to establish a statistically significant value.

\section{RESULTS}

\section{Demographic features of the participants}

The participants (604) were recruited from different colleges at Taif University. Most of them (62\%), are undergraduate students (85\%), single (76\%), and nonpregnant $(96 \%)$. As exhibited by Table 1 , around $15 \%$ of the surveyors were between the ages of 24-30 years and $31-45$ years. Further, only 22\% of them were married and about $17 \%$ had children. Additionally, only $10 \%$ of the participants had three or more children, while $3.8 \%$ and $3.3 \%$ of them had only two and one child, respectively. About $46 \%$ of the surveyors had no clue about the source of getting information about cord blood stem cell banking and donation, whereas 24\% admitted the role of the media in getting to know about cord banking.

\section{Knowledge analysis}

The frequency and percentage of correct replies to the knowledge domain items are shown in Table 2. Only 45 percent and 37 percent of participants in the 15-18 and 19-23 age groups, respectively, had any knowledge of stem cells or stem cell banking, which is statistically significant $(P=0.008)$. When compared to other cohorts, a significantly lower percentage of married participants $(P=0.011)$ have never heard of stem cell banking. When compared to any other source of information, the media received $68 \%$ of the participants' credit for learning about stem cell banking. When compared to other sources, the media transferred knowledge regarding the source of umbilical cord stem cells and their benefits to the participants who were aware of it to a significant $(P=0.001)$ degree.

\begin{tabular}{|c|c|c|}
\hline Demographics & Frequency & Percentage \\
\hline \multicolumn{3}{|c|}{ Age } \\
\hline $15-18$ years & 31 & $5.1 \%$ \\
\hline $19-23$ years & 375 & $62 \%$ \\
\hline $24-30$ years & 95 & $15.7 \%$ \\
\hline 31-45years & 86 & $14.2 \%$ \\
\hline$>45$ years & 17 & $2.83 \%$ \\
\hline \multicolumn{3}{|c|}{ Educational level } \\
\hline High school & 50 & $8.3 \%$ \\
\hline Undergraduate & 509 & $85 \%$ \\
\hline Postgraduate & 40 & $6.7 \%$ \\
\hline \multicolumn{3}{|c|}{ Marital status } \\
\hline Single & 462 & $76.4 \%$ \\
\hline Married & 134 & $22.1 \%$ \\
\hline Divorced & 5 & $0.8 \%$ \\
\hline Widow & 3 & $0.5 \%$ \\
\hline \multicolumn{3}{|c|}{ Pregnancy status } \\
\hline No & 584 & $96.5 \%$ \\
\hline Yes & 20 & $3.3 \%$ \\
\hline \multicolumn{3}{|c|}{ Having children } \\
\hline No & 500 & $82.6 \%$ \\
\hline Yes & 104 & $17.2 \%$ \\
\hline \multicolumn{3}{|c|}{ Number of Children } \\
\hline 0 & 500 & $82.6 \%$ \\
\hline 1 & 20 & $3.31 \%$ \\
\hline 2 & 23 & $3.8 \%$ \\
\hline 3 & 61 & $10.1 \%$ \\
\hline \multicolumn{3}{|c|}{ Source of information } \\
\hline Family member & 22 & $3.6 \%$ \\
\hline University & 109 & $18 \%$ \\
\hline Clinical & 28 & $4.6 \%$ \\
\hline School & 12 & $2 \%$ \\
\hline Have no idea & 273 & $45.1 \%$ \\
\hline Media & 160 & $26.4 \%$ \\
\hline
\end{tabular}




\begin{tabular}{|c|c|c|c|c|}
\hline Demographics & K1, n (\%) & K2, n (\%) & K3, n (\%) & $K 4, n(\%$ \\
\hline \multicolumn{5}{|c|}{ Age } \\
\hline $15-18$ years & $170(45)$ & $132(35)$ & $152(41)$ & $161(43)$ \\
\hline $19-23$ years & $35(37)$ & $26(27)$ & $36(38)$ & 37 (39) \\
\hline $24-30$ years & $22(26)$ & $21(24)$ & $37(43)$ & $24(28)$ \\
\hline $31-45 y e a r s$ & $5(29)$ & $5(29)$ & $4(24)$ & $7(41)$ \\
\hline$>45$ years & $10(32)$ & $5(16)$ & $17(55)$ & $10(32)$ \\
\hline$P$ value & 0.008 & 0.073 & 0.272 & .117 \\
\hline \multicolumn{5}{|c|}{ Pregnancy status } \\
\hline No & $236(40)$ & $182(31)$ & $237(41)$ & $232(40)$ \\
\hline Yes & $6(30)$ & $7(35)$ & $9(45)$ & $7(35)$ \\
\hline$P$ value & 0.487 & 0.807 & 0.818 & 0.817 \\
\hline \multicolumn{5}{|c|}{ Marital status } \\
\hline Single & $202(44)$ & $149(32)$ & $191(41)$ & $191(41)$ \\
\hline Married & $38(28)$ & $38(29)$ & $52(39)$ & $46(34)$ \\
\hline Divorced & $1(33)$ & $1(20)$ & $1(20)$ & $2(40)$ \\
\hline Widow & $1(33)$ & $1(20)$ & $2(67)$ & 0 \\
\hline$P$ value & 0.011 & 0.792 & 0.572 & 0.250 \\
\hline \multicolumn{5}{|c|}{ Educational level } \\
\hline High school & $16(32)$ & $11(22)$ & $23(46)$ & $16(32)$ \\
\hline Undergraduates & $204(40)$ & $159(31)$ & $208(41)$ & $199(39)$ \\
\hline Postgraduate & $20(50)$ & $18(45)$ & $11(28)$ & $22(55)$ \\
\hline$P$ value & 0.223 & 0.064 & 0.177 & 0.073 \\
\hline No & $209(42)$ & $157(31)$ & $204(41)$ & $201(40)$ \\
\hline Yes & $33(32)$ & $32(31)$ & $42(40)$ & $38(37)$ \\
\hline$P$ value & 0.062 & 1.00 & 1.00 & 0.510 \\
\hline \multicolumn{5}{|c|}{ Number of Children } \\
\hline 0 & $207(42)$ & $154(31)$ & $200(41)$ & $200(41)$ \\
\hline 1 & $10(39)$ & $11(42)$ & $10(39)$ & $11(42)$ \\
\hline 2 & $11(48)$ & $10(44)$ & $11(48)$ & $9(39)$ \\
\hline 3 & $14(23)$ & $14(23)$ & $25(41)$ & $19(31)$ \\
\hline$P$ value & 0.033 & 0.169 & 0.908 & 0.559 \\
\hline \multicolumn{5}{|c|}{ Source of information } \\
\hline Family member & $13(59)$ & $10(46)$ & $9(41)$ & $11(50)$ \\
\hline University & $87(80)$ & $82(75)$ & $26(24)$ & $88(81)$ \\
\hline Clinical & $12(43)$ & $9(32)$ & $16(57)$ & $18(64)$ \\
\hline School & $10(83)$ & $5(42)$ & $3(25)$ & $9(75)$ \\
\hline Have no idea & $11(4)$ & $6(2)$ & $121(44)$ & $7(3)$ \\
\hline Media & $109(68)$ & $77(48)$ & $71(44)$ & $106(66)$ \\
\hline$P$ value & 0.001 & 0.001 & 0.002 & 0.001 \\
\hline
\end{tabular}

Pearson Chi-Square significance: $P$ value; K1: Do you have information about stem cells and stem cell banking; K2: - Do you know the source of umbilical cord stem cells; K3: Do you think there are any health risk associated with umbilical cord stem cells collection; K4: Are you aware of the benefit from storing the umbilical cord stem cells.

\section{Attitude analysis}

Generally, the attitudes of the participants in this study were positive and inspiring (Table 3). Most of the participants of this study would like to get more information about umbilical cord stem cells and banking irrespective of their age group, marital status, and educational level with or without children. Significantly high percentage of the participants from younger age groups, and those who have children would like to store their umbilical cord stem cells. All sources of information have contributed significantly to develop desire to store umbilical cord stem cell among the study subjects. High percentage of participants of the study have also expressed their desire to donate umbilical cord stem cells to treat other patients as well as for research purposes.

\section{Analysis of participants' response}

Based on knowledge and attitude scores, Table 4 shows the percentage and frequency distribution of the participants. Only 4.8 percent of the study participants received a maximum knowledge score of 4 , while nearly a quarter had a score of 3 . Unfortunately, more than $26 \%$ of the surveyors received no knowledge score, while another $30 \%$ received only one grade out of a possible four. In comparison to knowledge, the study subjects' attitude scores were good. About $38 \%$ of them received a perfect score (4 out of 4) and another 22.4 percent received a 3 out of 4 marks. In the attitude score, only 4.5 percent of them failed to open their account.

\section{DISCUSSION}

The knowledge and attitudes of university students about stem cells are crucial because they will serve as a reliable source of information for patients, boosting their decision-making skills when it comes to adopting stem cells as a novel therapeutic strategy. ${ }^{12}$ The goal of this study was to determine the overall knowledge and attitude about umbilical cord stem cell banking (CB) among female Taif University students, as they will be the society's future trend setters. A total of 604 people were surveyed to find out how much they knew about CB banking and how they felt about it.

The bulk of the participants (70\%) had insufficient knowledge (less than or equal to 2 out of 4), but their attitudes were inspiring, with more than $60 \%$ of them scoring better than adequate (more than or equal to 3 out of 4). Unfortunately, several countries, ${ }^{13,14}$ have low levels of knowledge about CB banking. According to a prior study done in five European countries, 79 


\begin{tabular}{|c|c|c|c|c|}
\hline Demographics & A1, n (\%) & A2, n (\%) & A3, n (\%) & A4, n (\%) \\
\hline \multicolumn{5}{|c|}{ Age } \\
\hline $15-18$ years & $338(90)$ & $242(65)$ & $267(71)$ & $203(54)$ \\
\hline $19-23$ years & $86(91)$ & $64(67)$ & $75(79)$ & $43(45)$ \\
\hline $24-30$ years & $79(92)$ & $45(52)$ & $66(77)$ & $42(49)$ \\
\hline 31-45years & $17(100)$ & $7(41)$ & $10(59)$ & $8(47)$ \\
\hline$>45$ years & $26(84)$ & $11(36)$ & $18(58)$ & $11(36)$ \\
\hline$P$ value & 0.467 & 0.001 & 0.098 & 0.201 \\
\hline \multicolumn{5}{|c|}{ Pregnancy status } \\
\hline No & $529(91)$ & $356(61)$ & $419(72)$ & $295(51)$ \\
\hline Yes & $17(85)$ & $13(65)$ & $17(85)$ & $12(60)$ \\
\hline$P$ value & 0.428 & 0.715 & 0.308 & 0.497 \\
\hline \multicolumn{5}{|c|}{ Marital status } \\
\hline Single & $414(90)$ & $289(63)$ & $326(71)$ & $239(52)$ \\
\hline Married & $126(94)$ & $74(55)$ & $105(78)$ & $64(48)$ \\
\hline Divorced & $4(80)$ & $5(100)$ & $4(80)$ & $3(60)$ \\
\hline Widow & $2(67)$ & $1(33)$ & $1(33)$ & $1(33)$ \\
\hline$P$ value & 0.177 & 0.089 & 0.135 & 0.755 \\
\hline \multicolumn{5}{|c|}{ Educational level } \\
\hline High School & $44(88)$ & $30(60)$ & $39(78)$ & $28(56)$ \\
\hline Undergraduates & $463(91)$ & $315(62)$ & $365(72)$ & $259(51)$ \\
\hline Postgraduate & $35(88)$ & $24(60)$ & $29(73)$ & $18(45)$ \\
\hline$P$ value & 0.635 & 0.944 & 0.638 & 0.583 \\
\hline \multicolumn{5}{|c|}{ Having Children } \\
\hline No & $448(90)$ & $313(63)$ & $357(71)$ & $261(52)$ \\
\hline Yes & $98(94)$ & $56(54)$ & $79(76)$ & $46(44)$ \\
\hline$P$ value & 0.199 & 0.099 & 0.400 & 0.161 \\
\hline \multicolumn{5}{|c|}{ Number of Children } \\
\hline 0 & $443(90)$ & $311(63)$ & $355(72)$ & $258(52)$ \\
\hline 1 & $24(92)$ & $13(50)$ & $21(81)$ & $13(50)$ \\
\hline 2 & $23(100)$ & $17(74)$ & $17(74)$ & $8(35)$ \\
\hline 3 & $56(92)$ & $28(46)$ & $43(71)$ & $28(46)$ \\
\hline$P$ value & 0.394 & 0.022 & 0.777 & 0.340 \\
\hline \multicolumn{5}{|c|}{ Source of information } \\
\hline Family member & $22(100)$ & $20(91)$ & $17(77)$ & $14(64)$ \\
\hline University & $104(95)$ & $91(84)$ & $82(75)$ & $74(68)$ \\
\hline Clinical & $23(82)$ & $18(64)$ & $18(64)$ & $15(54)$ \\
\hline School & $9(75)$ & $9(75)$ & $10(83)$ & $7(58)$ \\
\hline Have no idea & $233(85)$ & $118(43)$ & $190(70)$ & $109(40)$ \\
\hline Media & $155(97)$ & $113(71)$ & $119(74)$ & $88(55)$ \\
\hline$P$ value & 0.001 & 0.001 & 0.594 & 0.001 \\
\hline
\end{tabular}

Pearson Chi-Square significance: $P$ value; $A 1$ : Would you like to receive information about umbilical cord stem cells and banking; $A 2$ : Do you consider storing your umbilical cord stem cells; $A_{3}$ : Would you donate your umbilical cord stem cells to treat other patients; $A_{4}$ : Would you donate your umbilical cord stem cells for research purpose.

\begin{tabular}{|c|c|c|c|c|c|}
\hline \multicolumn{3}{|c|}{ Knowledge Score } & \multicolumn{3}{|c|}{ Attitude Score } \\
\hline $\begin{array}{l}\text { ¿̊ } \\
\text { ஹ }\end{array}$ & 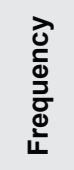 & 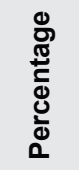 & 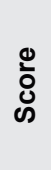 & $\begin{array}{l}\text { ठ̀ } \\
\frac{C}{0} \\
\frac{\Xi}{0} \\
\frac{d}{4}\end{array}$ & 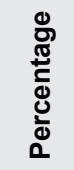 \\
\hline 0 & 160 & 26.5 & 0 & 27 & 4.5 \\
\hline 1 & 179 & 29.6 & 1 & 91 & 15.1 \\
\hline 2 & 87 & 14.4 & 2 & 121 & 20 \\
\hline 3 & 149 & 24.7 & 3 & 135 & 22.4 \\
\hline 4 & 29 & 4.8 & 4 & 230 & 38.1 \\
\hline
\end{tabular}

percent of those surveyed had limited knowledge of $\mathrm{CB}$ banking. ${ }^{15} \mathrm{~A}$ more recent study in India found similar results, with only $26 \%$ of individuals knowing what $\mathrm{CB}$ banking meant. ${ }^{10}$ According to a survey conducted in Greece, $48 \%$ of respondents knew everything there was to know about CB donation and storage. ${ }^{16}$ In Australia, where $70 \%$ of people were aware of $\mathrm{CB}$ banking, ${ }^{11}$ there was a higher level of awareness.

The majority of those who had heard about cord blood banking were informed primarily through the media, with just a handful being briefed by medical personnel-a trend that has been observed in other countries. ${ }^{15}$ As per the observation of one of the study ${ }^{17}$ the medical staff's lack of understanding prevents them from leading confident discussions on $\mathrm{CB}$ banking. As they're on the front lines and most people prefer to acquire such information from their health care providers, it is vital to provide accurate and thorough information about $\mathrm{CB}$ banking and current therapeutic use to our medical staff or health care providers. Getting information solely from social media could lead to misleading information, which could impact people's decisions about whether to donate their cord blood. Providing educational sessions to medical professionals will raise patient and family awareness from a non-profit source. Surprisingly, the participants' attitudes on CB donation were positive, and most of them were willing to donate for research and the treatment of other patients. This mindset will aid in the expansion of our CB donor pool for allogeneic stem cell transplantation. The attitude of giving to aid in the creation of new treatments and advancements in the field of stem cell research. Comprehensive educational campaigns providing clear and correct information on CB banking to university students, particularly in Saudi Arabia, are highly recommended. This will help to foster good attitudes toward CB donation and scientific research. 


\section{CONCLUSION}

Overall, Taif University female students' knowledge about umbilical cord stem cell banking and donation is limited, but their attitude is inspiring. A large percentage of students are interested in donating their umbilical cords for banking and storage for research and medical purposes. As a consequence of this study, it is advised that colleges adopt various stem cell educational programs and awareness campaigns in order to promote stem cell knowledge and attitudes, allowing the benefits of umbilical cord stem cell use to become more widely known in society.

\section{Funding}

Majid Alhomrani would like to acknowledge Taif University for support No. TURSP (2020/257).

\section{CONFLICT OF INTEREST}

The authors declare that there is no conflict of interest.

\section{REFERENCES}

1. Broxmeyer HE, Douglas GW, Hangoc G, Cooper S, Bard J, English D, et al. Human umbilical cord blood as a potential source of transplantable hematopoietic stem/progenitor cells. Proc Natl Acad Sci U S A. 1989 May 1;86(10):3828-32. doi: 10.1073/pnas.86.10.3828, PMID 2566997.

2. Kuwatsuka Y, Kanda J, Yamazaki H, Mori T, Miyamura K, Kako S, et al. Japan Society for Hematopoietic Cell Transplantation. A comparison of outcomes for cord blood transplantation and unrelated bone marrow transplantation in adult aplastic anemia. Biol Blood Marrow Transplant. 2016 Oct 1;22(10):1836-43. doi: 10.1016/j.bbmt.2016.07.002, PMID 27401034.

3. Rocha V, Cornish J, Sievers EL, Filipovich A, Locatelli F, Peters C, et al. Comparison of outcomes of unrelated bone marrow and umbilical cord blood transplants in children with acute leukemia. Blood. 2001 May 15;97(10):2962-71. doi: 10.1182/blood.v97.10.2962, PMID 11342418.

4. Laughlin MJ, Eapen M, Rubinstein P, Wagner JE, Zhang MJ, Champlin RE, et al. Outcomes after transplantation of cord blood or bone marrow from unrelated donors in adults with leukemia. N Engl J Med. 2004 Nov 25;351(22):2265-75. doi: 10.1056/NEJMoa041276, PMID 15564543.

5. Woodard P, Carpenter PA, Davies SM, Gross TG, He W, Zhang MJ, et al. Unrelated donor bone marrow transplantation for myelodysplastic syndrome in children. Biol Blood Marrow Transplant. 2011 May 1;17(5):723-8. doi: 10.1016/j.bbmt.2010.08.016, PMID 20813197.

6. Ruggeri A, Eapen M, Scaravadou A, Cairo MS, Bhatia M, Kurtzberg J, et al. Eurocord Registry, Center for International Blood and Marrow Transplant Research, New York Blood Center. Umbilical cord blood transplantation for children with thalassemia and sickle cell disease. Biol Blood Marrow
Transplant. 2011 Sep 1;17(9):1375-82. doi: 10.1016/j.bbmt.2011.01.012, PMID 21277376.

7. Gluckman E, Rocha V, lonescu I, Bierings M, Harris RE, Wagner J, et al. Results of unrelated cord blood transplant in fanconi anemia patients: risk factor analysis for engraftment and survival. Biol Blood Marrow Transplant. 2007 Sep 1;13(9):1073-82. doi: 10.1016/j.bbmt.2007.05.015, PMID 17697970.

8. Tsuji Y, Imai K, Kajiwara M, Aoki Y, Isoda T, Tomizawa D, et al. Hematopoietic stem cell transplantation for 30 patients with primary immunodeficiency diseases: 20 Year's experience of a single team. Bone Marrow Transplant. 2006 Mar;37(5):469-77. doi: 10.1038/sj.bmt.1705273, PMID 16435016.

9. Jawdat D, AITwijri S, AISemari H, Saade M, Alaskar A. Public awareness on cord blood banking in Saudi Arabia. Stem Cells Int. 2018 Apr 3;2018:8037965. doi: 10.1155/2018/8037965, PMID 29765424.

10. Pandey D, Kaur S, Kamath A. Banking umbilical cord blood (UCB) stem cells: Awareness, attitude and expectations of potential donors from one of the largest potential repository (India). PLOS ONE. 2016 May 26;11(5):e0155782. doi: 10.1371/journal.pone.0155782, PMID 27228155.

11. Jordens CF, Kerridge IH, Stewart CL, O'Brien TA, Samuel G, Porter M, et al. Knowledge, beliefs, and decisions of pregnant Australian women concerning donation and storage of umbilical cord blood: A population-based survey. Birth. 2014 Dec;41(4):360-6. doi: 10.1111/birt.12121, PMID 24988997.

12. Tork H, Alraffaa S, Almutairi K, Alshammari N, Alharbi A, Alonzi A. Stem cells: Knowledge and attitude among health care providers in Qassim region, KSA. Int J Adv Nurs Stud. 2017;7(1):1. doi: 10.14419/ijans.v7i1.8524.

13. Fernandez CV, Gordon K, Van den Hof M, Taweel S, Baylis F. Knowledge and attitudes of pregnant women with regard to collection, testing and banking of cord blood stem cells. CMAJ. 2003 Mar 18;168(6):695-8. PMID 12642424.

14. Lu $\mathrm{H}$, Chen $\mathrm{Y}$, Lan $\mathrm{Q}$, Liao $\mathrm{H}, \mathrm{Wu} \mathrm{J}$, Xiao $\mathrm{H}$, et al. Factors that influence a mother's willingness to preserve umbilical cord blood: A survey of 5120 Chinese mothers. PLOS ONE. 2015 Dec 9;10(12):e0144001. doi: 10.1371/ journal.pone.0144001, PMID 26650509.

15. Katz G, Mills A, Garcia J, Hooper K, McGuckin C, Platz A, et al. Banking cord blood stem cells: Attitude and knowledge of pregnant women in five European countries. Transfusion. 2011 Mar;51(3):578-86. doi: 10.1111/j.15372995.2010.02954.x, PMID 21126259.

16. Karagiorgou LZ, Pantazopoulou MN, Mainas NC, Beloukas AI, Kriebardis AG. Knowledge about umbilical cord blood banking among Greek citizens. Blood Transfus. 2014 Jan;12;Suppl 1:s353-60. doi: 10.2450/2013.0297-12, PMID 24120604.

17. Walker T, Steckler D, Spellman S, Haven D, Welte K, Boo M. Awareness and acceptance of public cord blood banking among practicing obstetricians in the United States. Transfusion. 2012 Apr;52(4):787-93. doi: 10.1111/j.15372995.2011.03383.x, PMID 21981791.

Cite this article: Alhomrani M, Alamri AS, Alsanie WF, Alrobiey AE, Asiri RM, Alaseri SM, et al. Knowledge and Attitude of Taif University Students on Stem Cell Banking. Indian J of Pharmaceutical Education and Research. 2022;56(1):296-301. 